\title{
Why recognising and rewarding excellent teaching in universities matters for students
}

\section{Chalmers, Denise}

Office of the Deputy Vice-Chancellor Education, University of Western Australia, Australia

\begin{abstract}
There is greater focus on the quality of higher education teaching and how we reward and recognize excellent teaching. There are questions from governments about the quality of teaching and a desire to identify excellence. In Australia and beyond, higher education institutions have been working towards clarifying their criteria and expectations of what constitutes excellent teaching. They are reviewing their policies and practices to enable their excellent teachers to access development and support so they might be rewarded through promotion. An increasing number of universities and higher education institutions are now promoting their excellent teachers through to professor level. This is important not just for the academics and teachers themselves, but for the quality of education that students receive.
\end{abstract}

Keywords: Recognising and rewarding teaching excellence, higher education 


\section{Introduction}

Despite decades of arguing for the importance of recognising and rewarding excellent teaching in order to provide a quality learning experience for students, higher education institutions have made little headway towards achieving this. It should therefore not be surprising that governments and major stakeholders in the sector continue to express concern about the quality of teaching in higher education institutions and the quality of the student learning experience.

\section{Decades of neglect}

The lack of appropriate mechanisms that reward and recognition excellent teaching has been recognised for decades, yet little has changed over this time. Illustrative examples demonstrate this failure in the USA, UK, Europe and Australia.

In the United States, Boyer in his seminal paper 'Scholarship Reconsidered' (1990) argued that universities should recognize the richness of academic work and reward contributions in what he proposed were four different forms of scholarship - teaching, integration, application of knowledge and discovery. He also argued that academic reward systems should stress the forms of scholarship most closely aligned with the university mission. How disappointing then that in 2017, the Commission on the Future of Undergraduate Education asserts that "...good teaching is generally undervalued. Faculty are rarely trained, selected and assessed as teachers and their effectiveness as instructors is rarely recognised or rewarded" (2017, p 13). The Commission argues for a national priority to strengthen the student educational experience through addressing the "widespread inattention to teaching quality" (p22), including the reward and recognition of both tenuretrack and fixed terms teachers in higher education and includes providing stable professional working environments and careers.

In the United Kingdom, the influential Dearing Report (1997) stated that teaching was of low status in relation to research, promotion was awarded for disciplinary research performance, that little or no funding was available for research and development projects in learning and teaching and that there was no national policy on the quality of teaching (DfES, 2003; Gosling, 2004). Despite years of government and quality initiatives to enhance the status and quality of teaching (Chalmers, 2011), and changes evident in promotion to reward teaching excellence in UK higher education institutions, significant barriers were found to remain (Cashmore, Cane \& Cane, 2013). Research carried out in UK universities from 2008-2013 by Cashmore, Ramsden and colleagues documented the progress made on rewarding and recognising teaching, including the development of teaching criteria and ways in which they are measured and presented. They found that while there had been progress with more universities developing teaching criteria and evidence across the sector overall, there remained substantial variation in different types of 
universities and within the disciplinary communities. Of greatest concern was that limited progress had been made on embedding the teaching criteria and establishing standards within the institutional systems and policies, and the persistent scepticism among academic teachers worldwide that their teaching contributions would be recognised and rewarded with career progression. (Cashmore et al, 2013; Locke, 2014). Subsequently, the UK government white paper 'Success as a Knowledge Economy' (Crown, 2016) noted that "For too long, teaching has been the poor cousin of research. Skewed incentives have led to a progressive decline in the relative status of teaching as an activity" (2016 para 23, p. 12). This has contributed to the governments' decision to introduce the Teaching Excellence Framework (TEF).

In Europe, the European Commission (EC) report (2013) stated that while quality teaching should be a priority in the higher education institutions, their research indicated that a "real commitment to quality teaching was not universal, sporadic at best and frequently reliant on the enlightened commitment of a few individuals" (EC, 2013, p.14). The report noted that there were outstanding individual examples of practical support for up-skilling teachers and recognition and reward of effective teaching, but that these were rarely sustained over time. The EC group for the modernisation of higher education has prioritised quality teaching and learning noting that improvements to the quality of teaching and learning in higher education can bring about a 'sea change' for Europe's future. The EC endorsed a set of Guiding Principles for Quality Teaching (2013, p 15) identifying both institutional and individual responsibilities to ensure high quality of teaching through setting standards, and developing, recognising and rewarding those who demonstrate those standards.

In Australia, the national government instituted a number of teaching quality initiatives, primarily targeted at the institutional level. For example, from the mid 1990s, the government established national student surveys, reporting of student progression and institutional quality audits with a strong focus on teaching quality and processes. The Learning and Teaching Performance Fund (LTPF) scheme, established in 2003, was a controversial initiative designed to differentially reward the higher education providers that best demonstrated excellence in learning and teaching based on a limited number of quantitative and qualitative indicators. The rationale for the fund was to promote teaching quality within the sector and to place excellence in learning and teaching alongside research excellence.

The Australian Learning and Teaching Council (ALTC) was established in 2004 to provide a national focus to enhance learning and teaching in Australian higher education institutions. The ALTC was preceded by a number of limited-term committees to promote and support teaching and learning in higher education, with the first established in 1990. These provided funding for competitive grants and projects, for example, funding for professional development, using technology to enhance teaching and learning, student 
learning, research and discipline-based projects (Chalmers, 2007). The focus for these initiatives were individuals and teams within and across universities to provide them with access to competitive funding to parallel research funding models, encourage academics to engage in teaching and learning issues in scholarly ways and to enhance the overall quality of teaching and learning in universities.

Another initiative was the Australian Awards for University Teaching, established in 1997 to celebrate and reward excellence in university teaching. The national teaching awards were expanded over the years to include teams, disciplines and institutional programs. While these initiatives were well-received, and led to many changes in teaching and support for students, there remained limited changes in the policies and practices of institutional reward and recognition of teaching, particularly in the career progression and promotion of excellent teachers.

The teaching quality initiatives in Australia and the UK were designed in large part to address the perceived lack of change by institutions to recognize and reward teaching and to enhance the status of teaching relative to research. By establishing incentives, the governments wished to prompt universities to pay attention to the quality of their teaching and learning and to implement reward and recognition processes and practices that were comparable or equivalent to those in research. Yet as Probert (2013) noted, the inclination to separate out academic roles as 'teaching-focused' or 'teaching-intensive' (as distinct to teaching-research academic roles or in US terms, tenure track academics) as a way to build an alternative career path has, to date, done little to raise the status or recognition of excellent teaching. Blackmore's (2016) work on the prestige assigned to academic work contributes insight into the ways in which academic work is valued through the lens of a prestige economy and why teaching persistently retains its lower status in comparison to research in the eyes of both institutions and individuals.

These illustrative examples from the USA, UK, Europe and Australia all lead to the same conclusion: excellent teaching remains undervalued and poorly recognised and rewarded. More concerning is that institutions have failed to link the quality of teaching and the quality of student learning and engagement, despite the strong evidence that persistently and consistently demonstrates the relationship (Commission on the future of undergraduate education, 2017; EC, 2013)

\section{Australian University Teaching Criteria and Standards (AUTCAS)}

The Australian University Teaching Criteria and Standards (AUTCAS) Framework (Chalmers et al, 2014; 2015) was developed an exemplar framework for institutions to use to develop their own teaching criteria and standards, setting expectations for each level of appointment and indicators to guide the collection of evidence used to substantiate claims for performance and promotion (Chalmers \& Hunt, 2016). The impetus for the 
development of the AUTCAS framework was in response to changes in the higher education sector in the last decade that were occurring globally. Many Australian universities were increasingly recognising that quality teaching was a key feature in attracting and retaining students, and therefore enhancing standards of excellence in learning and teaching was critical to securing a competitive edge.

The AUTCAS project was designed as a national strategy for creating a teaching excellence framework that drew on good practice principles and evidence-based measures of teaching performance, selected on the basis that they contributed directly to student learning and engagement (Chalmers et al., 2014) . The AUTCAS framework was devised to be flexibly utilised and contextualised by institutions as a multi-dimensional resource to inform their recruitment, probation, promotions, professional development and policy development related to quality teaching. The AUTCAS was also designed to provide individual academics with clarity on expected levels of teaching performance for the purpose of career planning. The background and strategy for the AUTCAS project is described in "A national strategy for teaching excellence - one university at a time" (Chalmers \& Tucker, 2018). This work then led into a National Senior Teaching Fellowship program to extend the use and application of the AUTCAS framework across the Australian higher education sector and internationally.

The scope of the Fellowship program was extensive (Chalmers, 2018). It built on the AUTCAS work which initially had engaged 21 universities and professional teaching associations. It engaged with the higher education sector organisations such as Universities Australia and the Tertiary Education Quality and Standards Agency (TEQSA) and international organisations such as the Higher Education Academy and Ako Aotearoa.

In terms of number of institutions that have engaged in the Fellowship activities with their representatives in senior leadership roles (Hunt \& Chalmers, 2017), it is estimated that 60 Australian higher education institutions were involved, including the majority of the 40 universities. Internationally, more than 230 international institutions were involved through direct communication and/or participation in presentations and workshops through the Fellowship program 2015-2017. The outcomes of the Fellowship have contributed to the Australia tertiary sector's engagement in an evidence and standards-based approach to rewarding and recognising teaching and informed international initiatives.

This extensive engagement with the higher education sector across Australia and internationally has contributed to the conversation of what constitutes excellence in teaching and how it can be recognized and rewarded within instituions (Broughan, Steventon \& Cloude, 2018). More broadly, it is has contributed to a growing concensus on expectations of teaching standards and practices relevant for different academic levels of appointment. These are positive outcomes that offer the potential to significantly benefit not 
only teachers, but more importantly, their students. The critical point is that any teaching excellence criteria and expecations MUST be focused on criteria that have been substantiated by research to promote student learning and engagement.

\section{References}

Blackmore, P. (2016). Prestige in academic life: Excellence and exclusion. Oxon, UK. Routledge.

Boyer, E (1990). Scholarship reconsidered: Priorities of the professoriate. Carnegie Foundation for the Advancement of Teaching.

Broughan, C., Steventon, G., \& Clouder, L (Eds) (2018). Global Perspectives on Teaching Excellence: A new era for higher education. London: Taylor and Francis Books.

Cashmore A., \& Ramsden, P. (2009) Reward and recognition in higher education: Institutional policies and their implementation. York, HEA

Cashmore, A., Cane, C. \& Cane, R. (2013). Rebalancing promotion in the HE sector: is teaching excellence being rewarded? York, HEA.

Chalmers D, Cummings, R., Stoney, S, Tucker, B, Elliott, S, Wicking, R \& Jorre de St Jorre, T. (2014) Australian University Teaching Criteria and Standards Project: Final report. Canberra, OLT.

Chalmers D, Cummings, R., Stoney, S, Tucker, B, Elliott, S, Wicking, R \& Jorre de St Jorre, T. (2015) Australian University Teaching Criteria and Standards Project: Extension report Canberra, OLT.

Chalmers D., \& Hunt, L. (2016). Evaluating teaching. HERSDA Review of Higher Education, vol 3, p 25-55. http://herdsa.org.au/herdsa-review-higher-education-vol$\underline{3 / 25-55}$

Chalmers, D. (2007). A review of Australian and international quality systems and indicators of learning and teaching.V1.2. Report Canberra ALTC

Chalmers, D. (2011). Progress and challenges to the recognition and reward of the scholarship of teaching in higher education. Special issue: Institutional approaches to SoTL, Higher Education Research and Development Journal. 30(1), 25-38

Chalmers, D. (2017). Inhibiting creativity of supporting quality? A teaching standards framework. HERDSA News 39(1) Summer (pp. 3-4).

Chalmers, D. (2018). Recognising and rewarding teaching: Australian teaching standards and expert peer review. Fellowship program. http://recognisinguniteaching.edu.au/

Chalmers, D., \& Tucker, B (2018). A national strategy for teaching excellence - one university at a time (Chapter 7) In Broughan, C., Steventon, G., \& Clouder, L (Eds) 
Global Perspectives on Teaching Excellence: A new era for Higher Education. London: Taylor and Francis Books.

Commission on the future of undergraduate education (2017). The future of undergraduate education: the future of America. American Academy of Arts and Sciences. Cambridge, Massachusetts. https://www.amacad.org

Crown (2016). Success as a Knowledge economy: teaching excellence, social mobility and student choice. White paper presented to Parliament, UK. May https://www.gov.uk/government/uploads/system/uploads/attachment_data/file/523396/b is-16-265-success-as-a-knowledge-economy.pdf

Dearing Report (1997) formally known as the reports of the National Committee of Inquiry into Higher Education. London UK. Department of Education and Skills.

DfES. (2003). The future of higher education. London: Department for Education and Skills.

European Union (2013). Report to the European Commission on improving the quality of teaching and learning in Europe's higher education institutions. High Level Group on the Modernisation of Higher Education. Luxembourg: Publications Office of the European Union. June.

Gosling, D. (2004). The impact of a national policy to enhance teaching quality and the status, England, the United Kingdom. Quality Assurance in Education. 12(3), 136-149.

Hunt, L., \& Chalmers, D. (2017). Change leadership, management and strategies to promote quality university teaching and learning. In S. Mukerji, \& P. Tripathi (Eds.) Handbook of Research on Administration, Policy, and Leadership in Higher Education (pp. 377-403). Hershey.

Locke, W. (2014) Shifting academic careers: Implications for enhancing professionalism in teaching and supporting learning. York, HEA.

Probert, B. (2013) Teaching-focused academic appointments in Australian universities: recognition, specialisation, or stratification. Office of Learning and Teaching (OLT) 